\title{
Profuse warts revealing a WHIM syndrome
}

\section{Younes Barbach, Mohammed Chaouche, Abdellah Dah Cherif, Salim Gallouj, Fatima Zahra Mernissi}

\author{
Departement of Dermatology, CHU Hassan II, Fès, Morocco
}

Corresponding author: Dr. Younes Barbach, E-mail: dr.younes2011@gmail.com

Warts, hypogammaglobulinemia, recurrent infections, and myelokathexis (WHIM) syndrome is a rare autosomal dominant immune deficiency. It has been individualized since 1990, initially described in 1964 by Zuelzer-Krill [1]. Other symptoms include severe neutropenia, condyloma acuminate, malignancies (mainly carcinomas related to human papilloma virus infection), and B-cell lymphopenia with impaired antibody responses after vaccination. Patients may also present with or develop lymphopenia, monocytopenia, and deficiency of plasmacytoid dendritic cells in the circulation, with impairment in both innate and adaptive immunity. Mobilization of neutrophils can occur during acute infection. Thus, adequate neutrophil count should not rule out this condition, particularly if complete blood count is tested throughout the course of acute infections [2]. The prognosis for patients with WHIM depends in part on early recognition of the disorder, with aggressive medical intervention to reduce the frequency of recurrent bacterial infections,

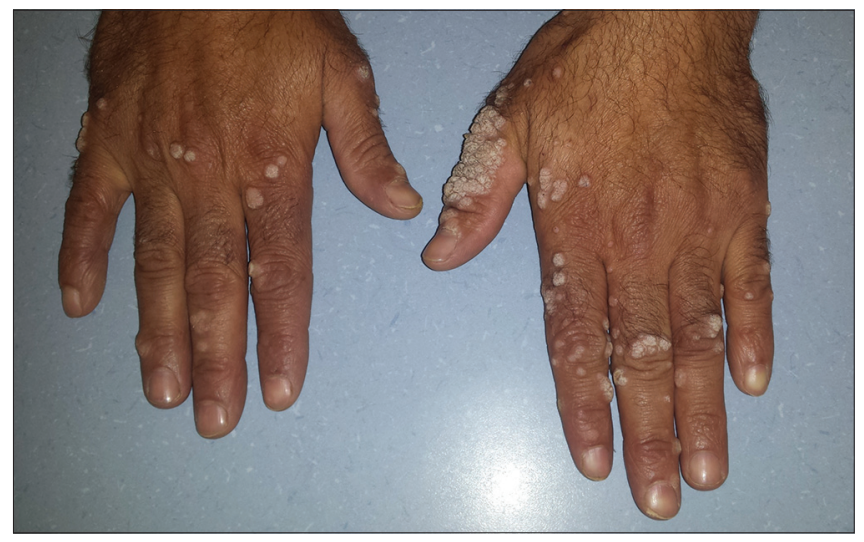

Figure 1: Vulgar warts diffused at the level of the 2 hands and to detect and extirpate in the early stages any HPV lesions that appear to be dysplastic or malignant [3].

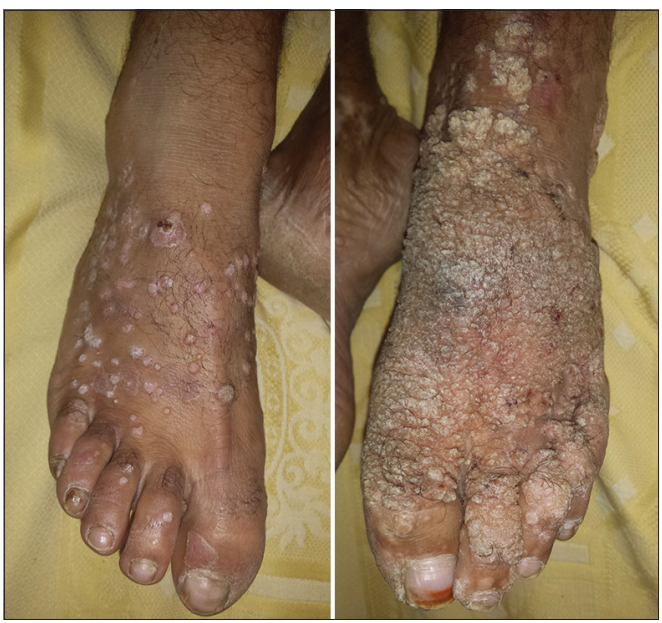

Figure 2-3: Diffuse vulgar warts at the level of 2 feet with the presence of a verrucous cupboard of the back of the left foot

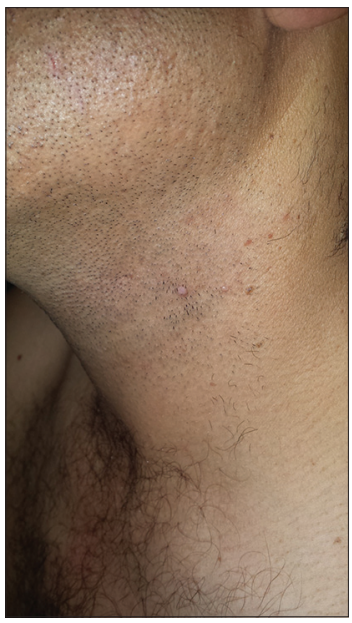

Figure 4: Multiple vulgar warts at the neck

How to cite this article: Barbach Y, Chaouche M, Cherif AD, Gallouj S, Mernissi FZ. Profuse warts revealing a WHIM syndrome. Our Dermatol Online. 2019;10(4):387-388.

Submission: 16.10.2018; Acceptance: 08.12.2018

DOI:10.7241/ourd.20194.19 
We report the case of a 34-year-old patient, with no similar case in the family, who for the last 8 years had profuse warts on the hands, feet and neck (Figs. 1 - 4), as well as recurrent episodes of skin bacterial infections. Biological exploration showed the presence of severe neutropenia and moderate hypogammaglobulinemia. The patient was initially put under salicylic acid, then oral retinoid and cimetidine, with average improvement of lesions and antibiotic prophylaxis to prevent bacterial superinfections.

\section{Consent}

The examination of the patient was conducted according to the Declaration of Helsinki principles.

\section{REFERENCES}

1. Bouregaa S, Hammadi H, Meddour Y, Younsi F, Timsiline M, Keniza H, et al. Verrues profuses révélant un syndrome WHIM: à propos d'un cas algérien. Ann Dermatol Vénéréologie. 2014;141(12, Suppl):S376-7.

2. Saettini F, Notarangelo LD, Biondi A, Bonanomi S. Neutropenia, hypogammaglobulinemia, and pneumonia: A case of WHIM syndrome. Pediatr Int. 2018;60:318-9.

3. Kawai T, Malech HL. WHIM Syndrome: Congenital Immune Deficiency Disease. Curr Opin Hematol. 2009;16:20-6.

Copyright by Younes Barbach, et al. This is an open access article distributed under the terms of the Creative Commons Attribution License, which permits unrestricted use, distribution, and reproduction in any medium, provided the original author and source are credited.

Source of Support: Nil, Conflict of Interest: None declared. 